\title{
Apoptotic and Anti-Metastatic Effect of Organotin Coordination Polymer on Human Hepatocellular Carcinoma (Hepg2) Cells via Intrinsic Pathway of Apoptosis
}

\author{
Mohammad Ibrahim Alallah ${ }^{1}$, Noura M Darwish2 ${ }^{2}$, Mohamed Soliman Elshikh $^{1}$ and M. Ajmal Ali ${ }^{1}$ \\ ${ }^{1}$ Department of Botany and Microbiology, College of Science, King Saud University, Riyadh, Saudi Arabia \\ ${ }^{2}$ Faculty of Science, Department of Biochemistry, Ain Shams University, Cairo, Egypt
}

${ }^{*}$ Corresponding author: Noura M. Darwish, Faculty of Science, Department of Biochemistry, Ain Shams University, Cairo, Egypt, Tel: 00201148145525; E-mail: noura-darwish@hotmail.com

Received Date: November 30, 2017; Accepted Date: December 18, 2017; Published Date: December 22, 2017

Citation: Alallah MI, Darwish NM, Elshikh MS, Ali MA (2017) Apoptotic and Anti-Metastatic Effect of Organotin Coordination Polymer on Human Hepatocellular Carcinoma (HepG2) Cells via Intrinsic Pathway of Apoptosis. Biochem Mol Biol J Vol. 3: No. 3: 21.

\section{Abstract}

Objective: Dysregulated activation of cellular signaling pathways was shown to be involved in hepatocellular carcinoma (HCC) progression This study focused on the investigation of the anticarcinogen activity of a tin (I) 3-Dsupramolecular coordination polymer (OSCP), a novel organotin supramolecular coordination polymers (SCP namely, $3 \infty[\mathrm{Ph} 3 \mathrm{SnCu}(\mathrm{CN}) 2 .(3-\mathrm{mpy}) 2] 3 \infty[\mathrm{Ph} 3 \mathrm{SnCu}(\mathrm{CN}) 2$. (3-mpy)2] on HepG2.

Design and Methods:This inhibitory effect was confirmed by cell proliferation assay, cell morphology examination, cell adhesion assay and DNA fragmentation. We have investigated the effects of OSCP on E-cadherin, $\beta$-catenin, $B C l-2$, and $B a x$ expression by both real time PCR and western blot analysis.

Results:The restrictive effect of OSCP compound on HepG2 cells' proliferation was evaluated by MTT assay. We observed that treated cells for $24 \mathrm{~h}$ with OSCP induced cell death in a dose-dependent manner. Furthermore, Western blot and real time PCR analysis revealed that $\mathrm{BCl}-2$ and $\beta$-catenin protein expression was inhibited after $24 \mathrm{~h}$ of treatment with OSCP, while Ecadherin and Bax expression increased after treatment, so OSCP can effectively inhibit the invasive potential of HepG2 cells by altering apoptosis and via inhibition of $\mathrm{BCl}-2$ and beta catenin which may play a significant role in this process.

Conclusion:These results confirmed the potential role of OSCP as an anticancerigen agent in hepatocarcinoma cell lines.

Keywords: OSCP; Bcl-2; Bax; E-cadherin; HepG2; $\beta$ catenin.

\section{Introduction}

Hepatocellular carcinoma ( $\mathrm{HCC}$ ) is one of the main globally reasons of death, killing up to 1 million people annually and accounts for about $90 \%$ of all histopathology types of primary liver cancers [1-3]. Conventional therapies at the early stages of this disease offer only a $50 \%$ chance of survival for five years. Therapeutic strategies of HCC were improved by both scientific and clinical advances, however poor prognosis of unrespectable cases still remains [4] and developing new therapeutic approaches is particularly urgent for HCC treatment. Hepatocellular carcinoma is characterized by the dysregulation of the balance between cell division and apoptosis, with decline in some pro-apoptotic signals, and increase in anti-apoptotic signals. Therefore, the predictive factor for the prognosis of HCC can provide valuable guidance for therapy [5].

Apoptosis may occur via a death receptor-dependent (extrinsic) or independent (intrinsic or mitochondrial) pathway. B-cell lymphoma $2(\mathrm{BCl}-2)$ is an anti-apoptotic protein that regulates apoptosis along the intrinsic mitochondrial apoptosis pathway. The expression of $\mathrm{BCl}-2$ in some tumor cell types inhibits cell adhesion and motility by enhancing actin polymerization [6-9]. $\mathrm{BCl}-2$ is an antiapoptotic factor interacts with Bax using its $\mathrm{BCl}$-2-homology (BH)-3-binding pockets leading to cell survival [10-14]. Loss of E-cadherin which has a reciprocal regulatory effect on the antiapoptotic $B \mathrm{Cl}-2$ is associated with $\beta$-catenin activation [15-17].

OSCP $\quad(3 \infty[\mathrm{Ph} 3 \mathrm{SnCu}(\mathrm{CN}) 2 \cdot(3-\mathrm{mpy}) 2] 3 \infty[\mathrm{Ph} 3 \mathrm{SnCu}(\mathrm{CN}) 2 \cdot(3-$ $\mathrm{mpy}) 2]$ ) is an organotin derivative. Organotin compounds were very promising potential drugs that were antitumor agents as they were found to exert a very good inhibitory effect against various human cancer cell lines [18-21]. However, the mechanism by which OSCP exerts its anticancer effects remains unclear. Therefore, the present study aimed to examine the anticancer potential of OSCP via apoptosis induction by exploring its effect on the expression level of the apoptotic proteins $\mathrm{Bax}$ and $\mathrm{BCl}-2$ and also to explore its effect on the cell adhesion molecule E-cadherin and $\beta$-catenin. 


\section{Materials and Methods}

\section{Reagents and antibodies}

OSCP and MTT dye were purchased from Sigma-Aldrich (St. Louis, MO, USA). Dulbecco's modified Eagle's medium (DMEM) obtained from (Gibco, CA, USA), Dimethyl Sulfoxide (DMSO), penicillin-streptomycin, and fetal bovine serum were purchased from Sigma Inc. Monoclonal antibodies to $\beta$ catenin, E-cadherin, $\mathrm{BCl}-2, \mathrm{Bax}$ and $\beta$-actin and secondary antibodies conjugated with horseradish peroxidase were purchased from Santa Cruz Biotechnology, USA. All other chemicals used in our experiment were of molecular biology grade.

\section{Cell culture}

Hepatocellular cancer HepG2 were obtained from American Type Culture Collection (ATCC, Rockville, MD) and were cultured in DMEM (Gibco, CA, USA) supplemented with $10 \%$ heat inactivated fetal bovine serum albumin (FBS), $2 \mathrm{mg} / \mathrm{mL}$ sodium bicarbonate and antibiotics $(100 \mu \mathrm{g} / \mathrm{mL}$ penicillin sodium salt and $100 \mu \mathrm{g} / \mathrm{mL}$ streptomycin sulfate) at $5 \% \mathrm{CO} 2$ at $37^{\circ} \mathrm{C}$ for $24 \mathrm{~h}$ as previously described [22]. Cells were grown to $70 \%$ confluence and then trypsinized with $0.25 \%$ trypsin/ $2 \mathrm{mM}$ EDTA. Adherent cultures were passaged at sub-confluence after trypsinization and sub cultured for experimental use.

\section{MTT assay}

Cell proliferation was determined using 3-(4, 5dimethylthiazol-2-yl)-2, 5-diphenyltetrazolium bromide (MTT) assay. HepG2 cells were plated in a 96-well tissue culture plate (Corning, NY, USA) at a density of $\left(5 \times 10^{3}\right.$ cells/well) and incubated at $37^{\circ} \mathrm{C}$ for $24 \mathrm{~h}$, and then treated with OSCP at different concentrations for $24 \mathrm{~h}$. Thereafter, $20 \mu \mathrm{l}$ of MTT solution (5 $\mathrm{mg} \mathrm{MTT/ml}$ in phosphate-buffered saline (PBS)) have been added into each well of the plate and incubated for $4 \mathrm{~h}$ at $37^{\circ} \mathrm{C}$. The resultant formazan product was dissolved in $200 \mu \mathrm{l}$ dimethylsulfoxide (DMSO)/well. The plates were shaked for $5 \mathrm{~min}$ at room temperature, so that complete dissolution of formazan was achieved. The MTT formazan absorbance was measured at $540 \mathrm{~nm}$ by a microplate reader (Model APW-100; BioTek, Hangzhou, China). OSCP was diluted in dimethyl sulfoxide (DMSO) to $10 \mathrm{mg} / \mathrm{mL}$ just before use. The IC50 value, the concentration OSCP required to inhibit cancer cell growth by $50 \%$ of the control level, was estimated from the plot.

\section{Growth properties}

To determine the population doubling time, about $2.5 \times$ $10^{5}$ viable cells were plated into $25 \mathrm{~cm}^{2}$ flasks. The number of cells was counted daily for at least 14 day. $0.4 \%$ trypan blue dye was used for cell viability determination and the number of viable cells was counted under a microscope using a hemocytometer. Mycoplasma contamination was tested by direct agar isolation and the Hoechst 33342 stain method (Microbiological Associates, Bethesda, MD) and rRNA based
PCR method [23]. HepG2 cell line was tested for bacterial contamination.

\section{Morphological characteristics}

HepG2 cells were cultured in 6-well plate. OSCP was added for medium at a concentration of IC50 and one half IC50 values ( $50 \mu \mathrm{M}$ and $25 \mu \mathrm{M}$, respectively). After treatment, all the cultures were incubated at $37^{\circ} \mathrm{C}, 5 \% \mathrm{CO}_{2}$ for $24 \mathrm{~h}$ then were washed well with phosphate buffered saline (PBS), fixed in $10 \%$ neutral formalin for $24 \mathrm{~h}$ and after processing they were embedded in paraffin for light microscopic examination. Photographs were taken under an inverted Leica fluorescence $40 \times 10$ microscope [24].

\section{Collagen I-coated wells preparation}

The first collagen solution of $3.0 \mathrm{mg} / \mathrm{mL}$ was diluted to 50.0 $\mu \mathrm{g} / \mathrm{ml}$ with sterile $1 \mathrm{x}$ phosphate buffered saline (PBS) on ice. For collagen I coating, a monolayer of diluted collagen I solution was applied to the $100 \mathrm{~mm}$ plastic dishes, $18 \mathrm{~mm}$ cover slips, 96-well plates, and 12-well plates under sterile condition and allowed to settle for 3-4 hours in a laminar hood followed by 24 hours of incubation at $37^{\circ} \mathrm{C}$ for the polymerization of the gel. After a fine layer of collagen I coat was formed, the cells were directly seeded on it.

\section{Cell proliferation assay}

HepG2 cells growing logarithmically were seeded in 96-well plates on both plastic and collagen l-coated matrices at the density of $0.5 \times 10^{4}$ cells/well. In all, 24 hours post-incubation in a $\mathrm{CO}_{2}$ incubator at $37^{\circ} \mathrm{C}$. OSCP treatment $(50 \mu \mathrm{M})$ was given for 24 hours. The medium containing OSCP was discarded and cell proliferation rate was measured using MTT assay as described earlier. The proliferation graph was plotted for both matrices.

\section{Cell adhesion assay}

HepG2 cells $\left(5 \times 10^{4} /\right.$ well $)$ treated with OSCP were suspended and added into 96-well micro-culture plates coated with collagen I and plastic matrice. After three hours of incubation, the medium was discarded followed by removal of unattached cells by gentle wash with $1 \mathrm{X}$ PBS. Cell images were captured in 10 different fields, and the attached cells were counted under microscope for both the matrices i.e., plastic and collagen I, and the graph of attached cells/field was plotted for each matrix.

\section{DNA and RNA extraction}

Total cellular DNA and RNA were obtained from washed cell pellets by homogenization in guanidine thiocyanate followed by centrifugation over a cesium chloride cushion. Subsequently, total genomic DNA was prepared by the proteinase $\mathrm{K}$ digestion and phenol chloroform extraction method [25]. 


\section{DNA agarose gel electrophoresis}

After treatment of cells with OSCP for $24 \mathrm{~h}$, the cultures were incubated at $37^{\circ} \mathrm{C}$ in an atmosphere containing $5 \% \mathrm{CO}_{2}$ and collected after $48 \mathrm{~h}$. Cells were washed twice with PBS and their genomic DNA was extracted according to Wang et al. [26]. The extracted DNA was electrophoresed on 1.5\% agarose gel and observed under UV transuliminator.

\section{Assay for Caspase-3/7,-8 and -9 activities}

A study of caspase-3/7, -8 and -9 activities was performed in triplicates using assay kits Caspase-Glo ${ }^{\circledR} 3 / 7,8$ and 9 (Promega, Madison, WI) on a 96-well microplate. A total of $1 \times 10^{5}$ cells were seeded per well and incubated with a final concentration of OSCP $50 \mu \mathrm{M}$ for 24 hours. Caspase activities were investigated according to the manufacture instructions. The caspase activities were measured using a Tecan Infinite ${ }^{\circledR} 200$ Pro (Tecan, Männedorf, Switzerland) microplate reader.

\section{Western blot analysis}

As previously described cells were plated at $1.5 \times 10^{4}$ into 6 well plates and treated with OSCP at concentrations of 25 and $50 \mu \mathrm{M}$ respectively. The cells were harvested, washed three times with PBS and lysed in protein lysis buffer containing protease inhibitors $(10 \mu \mathrm{g} \mathrm{ml}-1$ leupeptin, $2 \mathrm{mM}$ Phenylmethylsulfonylfluoride (PMSF) and $2 \mathrm{mM} \mathrm{Na3VO4).} \mathrm{Cell}$ lysates were centrifuged at $13,000 \times g$ at $4^{\circ} \mathrm{C}$ for $10 \mathrm{~min}$ to extract proteins. The protein concentration was estimated by Bradford reagents. SDS-PAGE was performed under reducing conditions on $10 \%$ polyacrylamide gels as described by Laemmli [27]. The proteins were transferred to a nitrocellulose membrane [28]. The blot was subjected to immunodetection with antibody against $B C l-2, B a x, E$-cadherin and $\beta$-catenine and $\beta$-actin was used as positive control. Secondary antibody to IgG conjugated to horseradish peroxidase was used.

\section{Real-time reverse transcription polymerase chain reaction}

A total of $2.0 \times 10^{5}$ cells/well was seeded in 24-well plates. Then cells were treated with OSCPeretin for $24 \mathrm{~h}$. Following treatment, RNA was extracted by TRIzol reagent. RNA samples were OSCPantified using NanoDrop spectrophotometer ND 2000 (Thermo Fisher Scientific, Waltham, MA, USA). $2 \mu \mathrm{g}$ of RNA were reverse transcriped to CDNA was synthesized following manufacturer's instructions of High-Capacity cDNA Reverse Transcriptase kit (Invitrogen, Carlsbad, CA, USA). Glyceraldehyde-3-phosphate dehydrogenase was considered as the endogenous expression standard. The $\Delta \Delta C \mathrm{t}$ method was used to calculate the relative fold change of the transcript [29]. The qRT-PCR was performed on a Rotor-gene 6000 System (Corbett Research, Mortlake, New South Wales, Australia) in $20 \mu \mathrm{L}$ qRT-PCR Master Mix (Qiagen). The reaction was performed under the following conditions: $94^{\circ} \mathrm{C}$ for 15 minutes; 45 cycles of $94^{\circ} \mathrm{C}$ for $15 \mathrm{~s}, 55^{\circ} \mathrm{C}$ for 40 seconds and $72^{\circ} \mathrm{C}$ for 20 seconds. Primer seOSCPences are shown in Table 1.

\section{Statistical analysis}

Statistical analysis was performed using one-way analysis of variance (ANOVA). Significant differences among means were estimated at $p<0.05$. The results were expressed as mean \pm SD. Values were analyzed using the SPSS 19.0 for Windows (SPSS, Chicago, IL, USA).

Table 1 Primer pairs used for real time quantitative PCR analyses.

\begin{tabular}{|c|c|c|c|}
\hline Gene & Primer sequence & Annealing temp & Reference \\
\hline GAPDH & $\begin{array}{l}\text { 5'-ССАСTCCTCCACCTTTGAC-3' } \\
\text { 5'-ACСCTGTTGCTGTAGCCA-3' }\end{array}$ & 60 & [30] \\
\hline$B c 1-2$ & $\begin{array}{l}\text { 5'-GGATGCCITTGIGGAACIGT-3' } \\
\text { 5'-AGCCIGCAGCTITGITTCAT-3' }\end{array}$ & 60 & [31] \\
\hline Bax & $\begin{array}{l}\text { 5'-TITGCTTCAGGCMCATCC-3' } \\
\text { 5'-CAGTTGAAGTIGCCGICAG A-3' }\end{array}$ & 58 & [31] \\
\hline E-cadherin & $\begin{array}{l}\text { 5'-CAGAAAGT1TTCCACCAAAAG-3' } \\
\text { 5'-ACTGAACCTGACCGTACACATGCCCTCATCTAATGTCT-3' }\end{array}$ & 58 & [30] \\
\hline$\beta$-catenine & $\begin{array}{l}\text { 5'-AGGGATTTTCTCAGTCCTTC-3' } \\
\text { 5'-ACTGAACCTGACCGTACACATGCCCTCATCTAATGTCT-3' }\end{array}$ & 58 & [30] \\
\hline
\end{tabular}

\section{Results}

\section{Determination of IC50 of OSCP}

The cytotoxic effect of OSCP was checked on HepG-2 and cell viability was estimated by MTT assay by exposing the cells to various concentration of OSCP ranging from $0 \mu \mathrm{M}$ to 100 $\mu \mathrm{M}$ for $24 \mathrm{~h}$. As shown in Figure 1, OSCP markedly reduced the viability of HepG-2 cells in a dose dependent manner $(P<0.05)$.

Moreover, the viability of HepG2 cells did not remarkably change at low concentration of OSCP thus suggesting that OSCP has dose-dependent inhibitory effects on HepG2 cells viability $(n=3 ; P<0.05)$. In all, 24 hours post-incubation with OSCP, the IC50 value obtained for HepG2 cells was $50 \mu \mathrm{M}$, the 
concentration at which the cell survival rate was reduced to $49.97 \%$ as correlated to the control population.

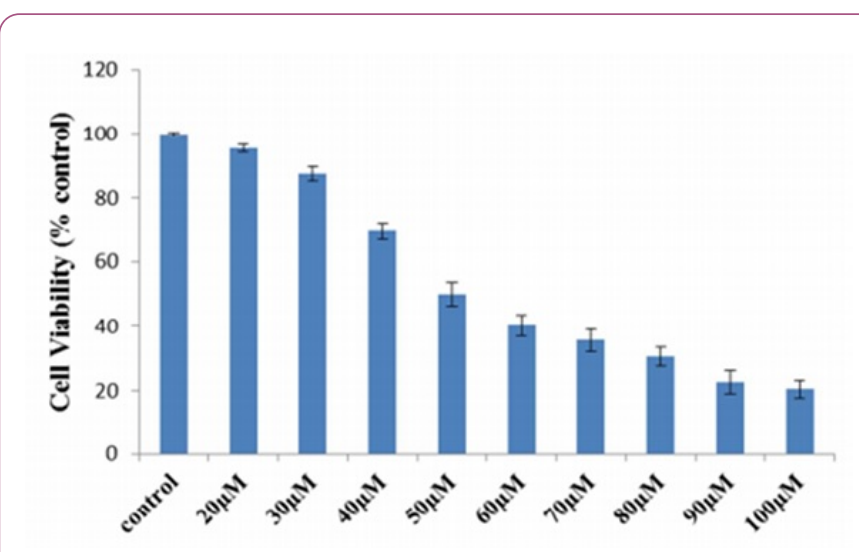

Figure 1 Dose-dependent effect of OSCP on HepG2 cell viability. Cells were exposed to varied concentrations of OSCP for $24 \mathrm{~h}$. Post-treatment MTT was performed, and absorbance was measured at $570 \mathrm{~nm}$.

\section{Cell proliferation assay}

HepG2 cells were treated with both plastic and collagen Icoated matrices to evaluate anti-proliferative effect of OSCP, and the results were analyzed using MTT assay. After 24 hours and 48 hours of treatment, MTT assay was performed as mentioned earlier and the graph of \% proliferation in comparison to the control cells was plotted (Figure 2). The graph depicts that the proliferation rate of the cells was remarkably reduced to $60 \%$ and $49.87 \%$ in the cases of collagen I-coated matrix and plastic matrix, respectively, post-24 hours of treatment.

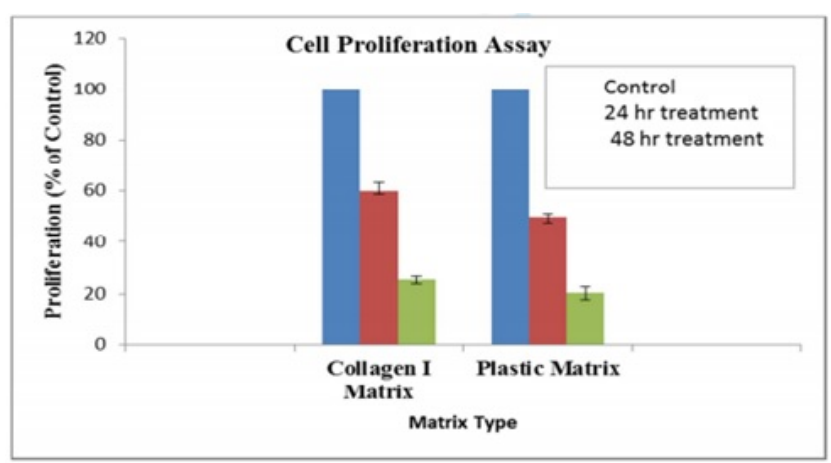

Figure 2 OSCP has anti-proliferative effect on both collagen and plastic matrices.

In the case of 48 hours of treatment, the reduction in the proliferation rate of cells was observed to be $36.2 \%$ and $28.36 \%$ for collagen I-coated matrix and plastic matrix, respectively, hence proving the anti-proliferative activity of OSCP in a time-dependent manner.
The data collectively showed that regardless of an enhancement in the proliferation rate of HepG2 cells due to collagen I, OSCP could ablate proliferation of cells.

\section{Cell adhesion assay}

Cell adhesion assay was used to evaluate the metastatic ability of HepG2 cells and to assess the effect of OSCP treatment on the ability of cells to adhere. To understand if the alteration of matrices intervenes with the difference in the proliferation rate of HepG2 cells due to variance in their adhesion property on both collagen I and plastic matrices, the adhesion property of the cells was determined in 24-well plates. After three hours of incubation, the medium was discarded and followed by removal of unattached cells by gentle wash with $1 \mathrm{X}$ PBS. Cell images were captured in 10 different fields, and the attached cells were counted under microscope for both the plastic and collagen I matrices, and the graph of attached cells/field was plotted for each matrix. It was observed that the cells exhibited significant difference in adhesion efficiency in different matrices, which could account for the different proliferation rates (Figure 3 ). Therefore, the growth modulation of HepG2 cells on both the matrices is dependent of their adhesion properties $(n=10)$.

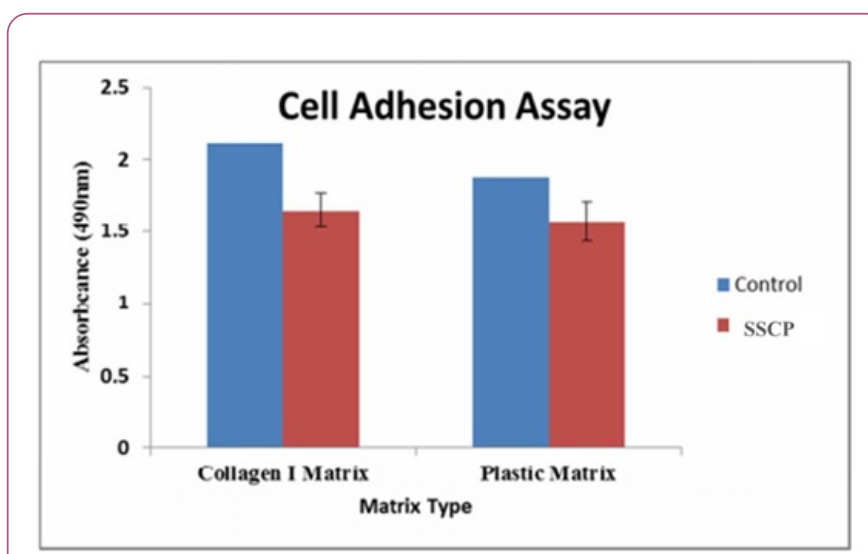

Figure 3 OSCP inhibited HepG2 adhesion to plastic matrix and collagen I.

\section{Morphologic studies}

First of all, to examine whether OSCP-induced cell death is associated with apoptosis, HepG2 cells were treated with IC50 concentration and half IC50 $\mu \mathrm{M}$ OSCP for $24 \mathrm{~h}$ and then analyzed for morphological changes. In this study light microscopic observation of the treated HepG2 cell line showed typical morphological features of apoptosis including the appearance of marked apoptotic bodies, cell shrinkage whereas control cells produced intact genomes (Figures 4A-4C). The apoptotic morphological changes assayed for OSCP were more evident at doses of IC50 (50 $\mu \mathrm{M})$ and half IC50 $(25 \mu \mathrm{M})$ of treatment with increase in apoptotic cells (Figures 4B and 4C) as cells were changed into round shapes, reduction in cell volume as compared to untreated HepG2 cells which showed a high confluency of monolayer cells which grew as an adherent pattern; they were monotonous spindle 
A

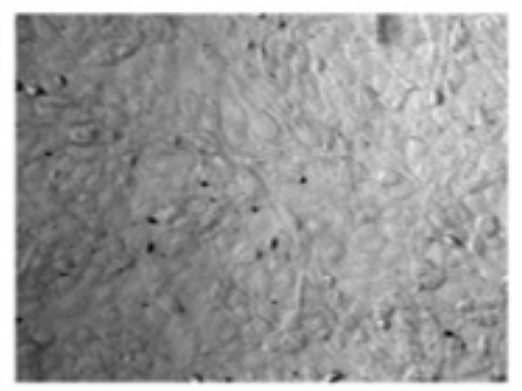

B

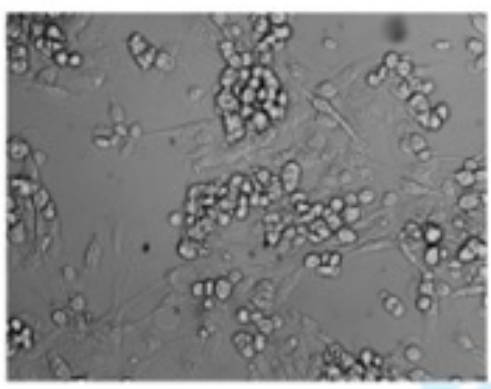

$\mathrm{C}$

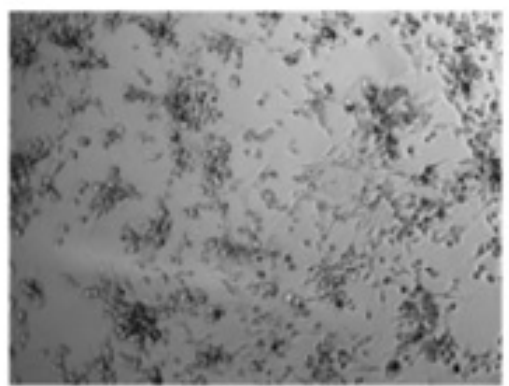

Figure 4 Morphological changes of HepG2 cells in response to OSCP at 40X 10 magnification microscopy. A: Normal HepG2 cells are large, polygonal cells with numerous variably sized clear vacuoles; B: OSCP $(25 \mu \mathrm{M})$ some morphological changes were presented, cells detached and blebbed; C: OSCP $(50 \mu \mathrm{M})$, cells have a loss of cytoplasmic vacuoles, cell shrinkage and rounding-up, and marked decrease in mitotic figures and increased numbers of apoptotic bodies. The results are from one representative experiment of three independently performed that showed similar patterns.

\section{DNA fragmentation assay}

To determine if the anti-proliferative effects of OSCP involve apoptosis as a mechanism, we employed a DNA fragmentation assay. transluminator after staining with ethidium bromide. Nuclear fragmentation was observed after $24 \mathrm{~h}$ of treatment with quercetin compound. Lane 1: Control; Lane 2: $50 \mu \mathrm{M}$ OSCP; Lane 3: $25 \mu \mathrm{M}$ OSCP. The results are from one representative experiment of three independently performed that showed similar pattern.

HepG2 cells were incubated with the tested compound for $24 \mathrm{~h}$ and then genomic DNA was extracted. The extracted DNA then was analyzed by gel electrophoresis. As shown in the result (Figure 5), cell genomic DNA showed the typical formation of DNA fragments as ladders after OSCP treatment and the interval of the ladders is about $100 \mathrm{bp}$. The DNA ladder was observed after $48 \mathrm{~h}$ of treatment. This phenomenon indicated that the apoptosis of HepG2 cells was induced by OSCP. DNA laddering indicates the presence of double-strand breaks (Figure 5). No fragments were detected in cells incubated in the absence of OSCP.

\section{Effect of OSCP on caspase activity in HepG2 cells}

To examine the molecular mechanism underlying apoptosis process, we determined the caspase- $3 / 7,-8$ and -9 activities by measuring the luminescence intensities after 24 hours of OSCP treatment. The activity of caspases-3, 7 and 9 in OSCP treated $(50 \mu \mathrm{M})$ HepG2 cells increased significantly $(P<0.01)$ after 24 hours of treatment $(3.87 \pm 0.38,2.31 \pm 0.21,1.76 \pm 0.18$ $\mu \mathrm{mol} / \mathrm{L}$ per microgram protein, respectively), compared with untreated cells $(1.44 \pm 0.24,0.72 \pm 0.18$ and $0.68 \pm 0.12$ $\mu \mathrm{mol} / \mathrm{L}$ per microgram protein, respectively) (Figure 6).

\section{Control $50 \mu \mathrm{M} \quad 25 \mu \mathrm{M}$}

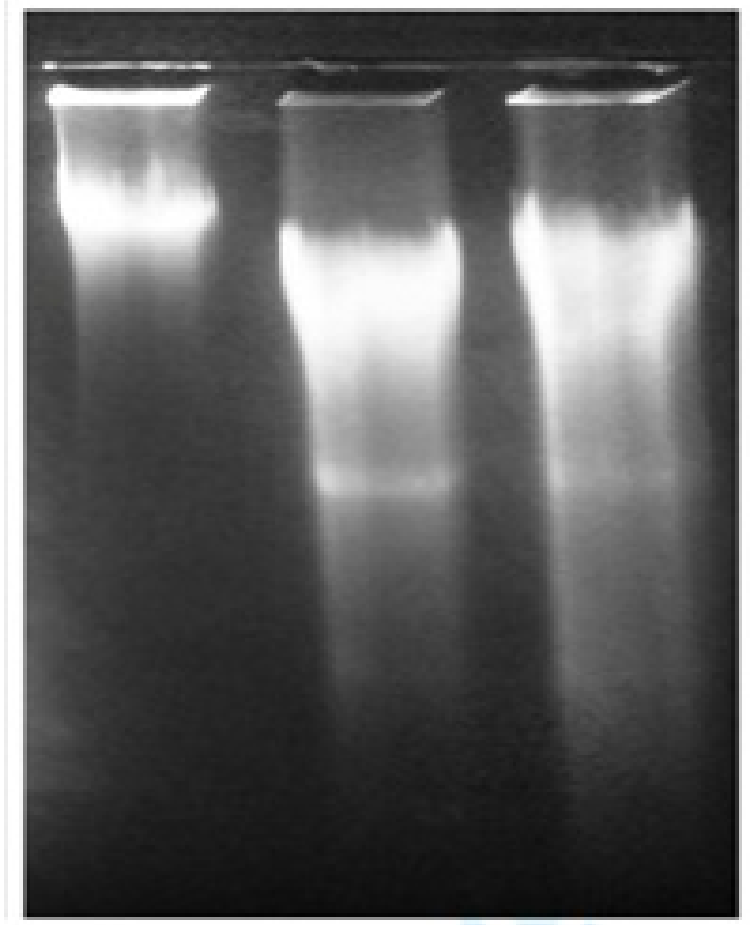

Figure $5 \mathrm{Gel}$ electrophoresis of DNA extracted from HepG2 cells. HepG2 cells were treated with IC50 for $24 \mathrm{~h}$. Cells were collected by centrifugation and DNA was extracted. The DNA fragments was separated on $1.5 \%$ agarose gel electrophoresis and visualized under UV

In contrast, there were no significant changes in the activity of caspase-8 $(2.1 \pm 0.15)$ for the time span of 24 hours in OSCP treated-HepG2 cells $(1.83 \pm 0.18 \mu \mathrm{mol} / \mathrm{L}$ per microgram protein, $\mathrm{P}>0.05$ ). 


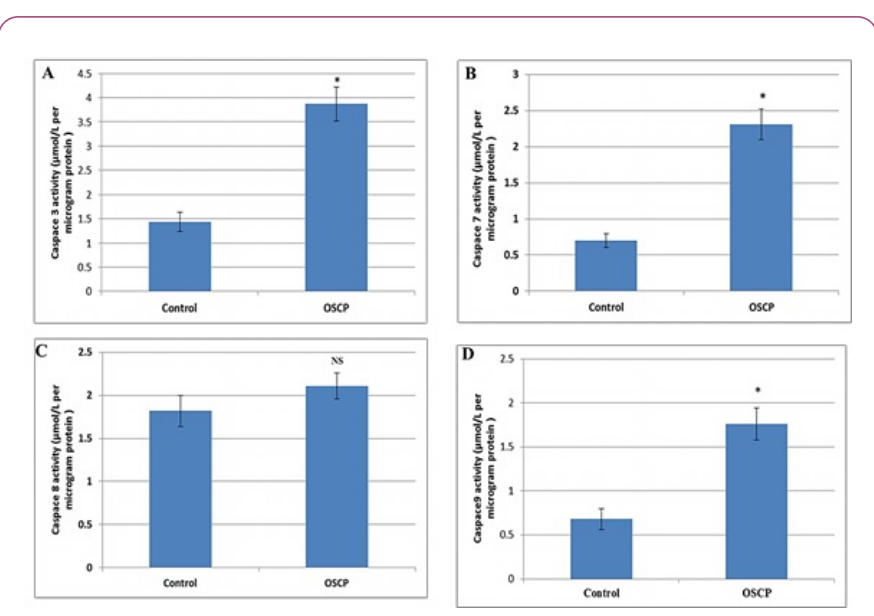

Figure 6 OSCP induces apoptosis through intrinsic caspase pathway. (A, B and D); Caspase-3, 7 and -9 were activated in HepG2 after OSCP treatment (50 $\mu \mathrm{M})(\mathrm{C})$; nonsignificant increase in caspase 8 activity was determined against vehicle (DMSO)-treated cells at 24-hour. Data were mean \pm SD. Data were representative of at least three similar experiments.

Our data suggested that OSCP induced activation of intrinsic caspase pathway in liver cancer cell line.

\section{Effect of OSCP on apoptosis and EMT modulators in HepG2 cells}

The expression level of the apoptotic markers under the effect of OSCP was also calculated in terms of relative fold change. As given in Figure 6 a significant up-regulation in the expression of markers such as Bax while there was a significant down-regulation of $\mathrm{BCl}-2$ was observed in the presence of OSCP as compared to untreated HepG2 cells (Figure 6), which affirms the role of OSCP in triggering the apoptosis in HepG2 cells. To interpret the mechanism involved in OSCP-directed prevention of EMT in HCC the mRNA expression levels of epithelial markers $\beta$-catenin and E-cadherin were analyzed using OSCP quantitative PCR [30]. As shown in Figure 6 there was a significant $(P<0.05)$ increase in the expression level of $E$ cadherin $(3.25 \pm 0.53)$ after $24 \mathrm{~h}$ treatment with $50 \mu \mathrm{M}$ OSCP. On contrast the expression level of $\beta$-catenin was significantly $(P<0.05)$ down-regulated by a $(-0.68 \pm 0.12)$ fold decrease when compared to untreated HepG2 cells. These results indicate that OSCP aids in maintaining the integrity of epithelial cells and prevents cell migration.

\section{Intrinsic apoptotic pathway is activated by OSCP treatment}

To further study the effect of OSCP on apoptotic mitochondrial pathway, western blot analysis was performed for both $\mathrm{BCl}-2$ and Bax proteins as the main mediators in intrinsic apoptotic pathway. $B c l-2$ expression level was decreased after $24 \mathrm{~h}$ treatment by OSCP whereas there was increased expression level of Bax protein (Figure 7).

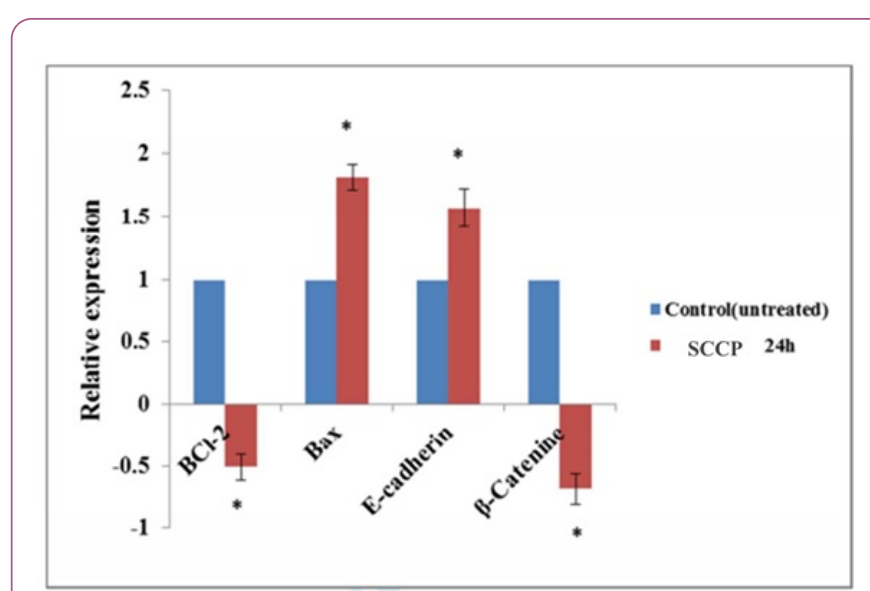

Figure 7 Gene expression in HepG2 cells after OSCP treatment $24 \mathrm{~h}$. Results are expressed as mean \pm SD.

This result suggests that OSCP treatment triggers mitochondria-dependent apoptosis in HepG2 cells [31].

\section{OSCP inhibits EMT in HepG2 cells}

Cell lysate was extracted from HrpG2 cells after $24 \mathrm{~h}$ OSCP treatment. These lysates were analyzed by Western blot for the expression E-cadherin and $\beta$ - catenin. As shown in Figure 7 and $D \beta$-catenin was found to have a decreased expression after treatment while E-cadherin was found to have enhanced expression level confirming the RT-PCR results and suggesting the potential role of OSCP in EMT prevention.

\section{Discussion}

Despite the presence of few therapeutic strategies for HCC, the development of novel effective drugs with low systemic toxicity is the primary focus of cancer research [32]. Recently, more attention was paid to natural chemical compounds, which were vital targets in anticancer field, because of the drug resistance and toxic side effects of current chemotherapy [33]. OSCP was found to have anticancer activity against different types of cancer, including prostate cancer, hepatocellular carcinoma and breast cancer [34-38]. However, to the best of our knowledge, the antimigratory and antiinvasive activity and the underlying mechanism of OSCP on HepG2 cells remains unclear.

Induction of apoptosis is one of the important targets as a preventive approach [39]. Apoptosis usually results in typical morphological and biochemical characteristics, including condensed chromatin in cells, shrinkage of cytoplasm and membrane blebbing, appearance of apoptotic bodies, and DNA ladder bands on agarose electrophoresis [40].

Our data showed that OSCP treatment significantly reduced cell proliferation and aggressive properties of HepG2 cells. The inhibitory effect of OSCP compound on HepG2 cells viability was exerted in a dose dependent manner. OSCP concentration that was found to give $50 \%$ of cell viability is $50 \pm 1.019 \mu \mathrm{M}$. DNA ladder formation was also observed after $24 \mathrm{~h}$ and $48 \mathrm{~h}$ 
treatment. Thus, these experiments suggested that OSCP could induce apoptosis of human liver carcinoma HepG2 cell line in vitro.
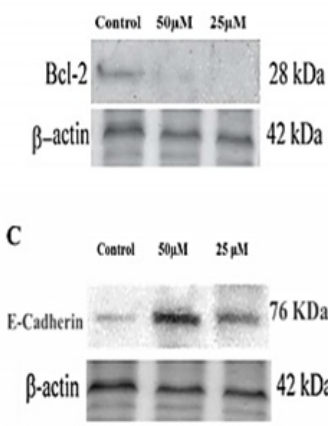

B Control $50 \mu \mathrm{MI} 25 \mu \mathrm{M}$

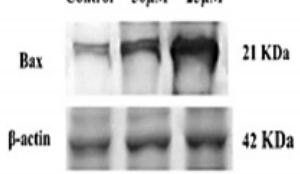

D

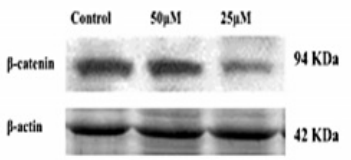

Figure 8 Western blot analysis of A: Bcl-2; B: Bax; C: Ecadherin; D: $\beta$-catenin protein expression in HepG2 after 24 h OSCP treatment.

These results come in agreement with previous results reported that OSCP possess anti-proliferation and antimigration capacity of cancer via different signaling pathways $[41,42]$. To define the mechanism by which OSCP restrict growth and induces apoptosis, we investigated the regulators of these processes including $\mathrm{BCl}-2$ and $\mathrm{Bax}$.

Apoptosis induction is the main therapeutic approach of many anticancer drugs by exerting cytotoxic effect on cancer cells [43-45]. Our results revealed that OSCP might induce apoptosis by upregulating $\mathrm{Bax}$ and down regulating $\mathrm{BCl}-2$ as shown in Figures 8A-8D, suggesting that the apoptotic effect of OSCP on HepG2 cells is exerted through the intrinsic mitochondrial pathway.

$B c l-2$ affects the phenotype of the original epithelial cells, and promotes epithelial-mesenchymal conversion, accompanied by loss of the cell adhesion molecules E-cadherin [46]. Interestingly, in our study, caspase-3,-7,-9 appeared to be significantly activated after $50 \mu \mathrm{M}$ OSCP treatment suggesting that in HepG2 cells OSCP probably causes apoptosis by a mitochondrial apoptosis pathway, although, there was a nonsignificant activation of the extrinsic pathway (caspase-8). Our results are consistent with previous studies that confirmed in vitro antiproliferative activity of organotin compounds [47].

Tumor metastasis was the greatest reasons of mortality. The complex processes of tumor invasion and metastasis included cell migration, adhesion, and invasion. E-cadherin, a key cellto-cell adhesion molecule, was relevant to the invasion and metastasis of cancer cells and could promote the development of cancer [48]. Loss of E-cadherin can initiate neoplastic transformation, but the molecular mechanisms still not well understood [49-51]. In addition, there is a reciprocal regulation between E-cadherin and $\mathrm{BCl} 2$ which provides an attractive new explanation of how E-cadherin activation might propel neoplastic transformation [52]. $\beta$-catenin bind to E-cadherin and transduces adhesion signals to the cell is important for cancer development [53-55]. Previous studies showed that loss of E-cadherin triggers upregulation of the anti-apoptotic $\mathrm{Bcl} 2$ and thereby increases cell survival [52]. This reciprocal regulation may be a critical determinant of early tumor development following $E$ - cadherin inactivation or loss of $\mathrm{E}$ cadherin expression [52].

\section{Conclusion}

In summary, treatment of HepG2 cells with OSCP induced growth inhibition in HepG2 cells and resulted in the appearance of marked apoptotic bodies and cell shrinkage. OSCP also up-regulated the cell adhesion molecule (Ecadherin) and the pro-apoptotic factor, Bax, and downregulated proliferative factor ( $\beta$-catenin) and the antiapoptotic factor ( $\mathrm{BCl}-2)$ expression. In addition, OSCP can lead to apoptosis and DNA fragmentation. Therefore, therapeutic strategies to selectively inhibit anti-apoptotic signals in HCC cells might have the potential to provide powerful tools in the future to treat liver cancer. This finding should be confirmed in a larger scale. OSCP compound can effectively inhibit the invasive potential of HCC cells by altering EMT, inhibition of $\beta$ catenin expression may play a significant role in this process. It also plays an inhibitory effect by apoptosis induction.

\section{Ethics approval and consent to participate}

The study protocol was approved by Ain Shams University, Faculty of Science Ethics Committee (REC number: PSU25112012).

\section{Availability of data and materials}

All materials and data are available and sharing is available.

\section{Author Contributions}

Authors completed the study protocol and were the main organizer of data collection drafting and revising the manuscript. Noura Darwish wrote the article and guarantees the paper. All authors contributed to the discussion and reviewed the manuscript and helped in designing the study and protocol and engaged in a critical discussion of the draft manuscript. All authors agreed on the final version of the manuscript.

\section{References}

1. Torre LA, BrayF, Siegel RL, Ferlay J, Lortet-Tieulent J, et al. (2015) Global cancer statistics, 2012. CA Cancer J Clin 65: 87-108.

2. Simonetti RG, Camma C, Fiorello F, Politi F, D'Amico G, et al. (1991) Hepatocellular carcinoma a worldwide problem and the major risk factors. Dig Dis Sci 36: 962-972.

3. Chen W, Zheng R, Baade PD, Zhang S, Zeng H, et al. (2016) Cancer statistics in China, 2015. CA Cancer J Clin 66:15-32. 
4. Schütte K, Bornschein J, Malfertheiner P (2009) Hepatocellular carcinoma-epidemiological trends and risk factors. Dig Dis 27: 80-92.

5. Maiuri MC, Zalckvar E, Kimchi A, Kroemer G (2007) Self-eating and self-killing: Crosstalk between autophagy and apoptosis. Nat Rev Mol Cell Biol 8: 741-752.

6. Mukhopadhyay S, Panda PK, Sinha N, Das DN, Bhutia SK (2014) Autophagy and apoptosis: Where do they meet? Apoptosis 19: 555-566.

7. Marino G, Niso-Santano M, Baehrecke EH, Kroemer G (2014) Self-consumption: The interplay of autophagy and apoptosis. Nat Rev Mol Cell Biol 15: 81-94.

8. Yang Z, Klionsky DJ 2010 Eaten alive: A history of macroautophagy. Nat Cell Biol 12: 814-822.

9. Ke H, Parron VI, Reece J, Zhang JY, Akiyama SK, et al. (2010) BCL2 inhibits cell adhesion, spreading, and motility by enhancing actin polymerization. Cell Res 20: 458-469.

10. Maiuri MC, Le Toumelin G, Criollo A, Rain JC, Gautier F, et al. (2015) Functional and physical interaction between $\mathrm{BCl}-\mathrm{XL}$ and a BH3-like domain in Beclin-1. Int J Mol Sci 16: 25757.

11. Pattingre S, Tassa A, Oscp X, Garuti R, Liang XH, et al. (2005) $\mathrm{BCl}-2$ antiapoptotic proteins inhibit Beclin 1-dependent autophagy. Cell 122: 927-939.

12. Zhou F, Yang $\mathrm{Y}$, Xing D (2011) Bcl-2 and Bcl-xL play important roles in the crosstalk between autophagy and apoptosis. FEBS J 278: 403-413.

13. Wei Y, Pattingre S, Sinha S, Bassik M, Levine BJ (2008) NK1mediated phosphorylation of $\mathrm{BCl}-2$ regulates starvation-induced autophagy. Mol Cell 30: 678-688.

14. Wei Y, Sinha S, Levine B (2008) Dual role of JNK1-mediated phosphorylation of $B C l-2$ in autophagy and apoptosis regulation. Autophagy 4: 949-951.

15. Van De Wetering, Barker M, Harkes N, Van Der Heyden IC, Dijk $M$, et al. (2001) Mutant E-cadherin breast cancer cells do not display constitutive Wnt signaling. Cancer Res 61: 278-284.

16. Schackmann RC, Van Amersfoort M, Haarhuis JH, Vlug EJ, Halim VA, et al. (2011) Cytosolic p120-catenin regulates growth of metastatic lobular carcinoma through Rock1-mediated anoikis resistance. J Clin Invest 212: 3176-88.

17. Vermeulen JF, Ven RA, Ercan C, Groep P, Wall E, et al. (2012) Nuclear Kaiso expression is associated with high grade and triple-negative invasive breast cancer. PLoS One 7: e37864.

18. Alama A, Tasso B, Novelli F, Sparatore F (2009) Organometallic compounds in oncology: Implications of novel organotins as antitumor agents. Drug Discov Today 14: 500-508.

19. Awang N, Kamaludin NF, Ghazali AR (2011) Cytotoxic effect of organotin (IV) benzylisopropyldithiocarbamate compounds on Chang liver cell and hepatocarcinoma HepG2 cell. Pak J Biol Sci 14:768-774.

20. Gielen M, Biesemans M, De Vos D Willem R (2000) Synthesis, characterization and in vitro antitumor activity of di- and triorganotin derivatives of polyoxa- and biologically relevant carboxylic acids. J Inorg Biochem. 2000; 79:139-145.

21. Lee SM, Mohd Ali H, Sim KS, Abdul Malek SN, Lo KM (2013) Synthesis, characterization and biological activity of diorganotin complexes with ONO terdentate Schiff base. Inorganica Chim Acta 406: 272-278.
22. Masters JR, Thomson JA, Daly-Burns B (2001) STR profiling provides an international reference standard for human cell lines. Proc Nat Acad Sci USA 98: 8012-8017

23. Vaughn JL, Goodwin RH, Tompkins GJ, McCawley P (1977) The establishment of two cell lines from the Insect Spodoptera frugiperda (Lepidoptera: Noctuidae). In Vitro 13: 213-217.

24. Wang J, Wilcken DE, Wang XL (2001) Cigarette smoke activates caspase- 3 to induce apoptosis of human umbilical venous endothelial cells. Mol Genet Metab 72: 82-88.

25. Yang FG, Zhang ZW, Xin DQ, Shi CJ, Wu JP, et al. (2005) Peroxisome proliferator-activated receptor gamma ligands induce cell cycle arrest and apoptosis in human renal carcinoma cell lines. Acta Pharmacol Sin 26: 753-761.

26. Liu H, Zang C, Fenner MH, Liu D, Possinger K, et al. (2006) Growth inhibition and apoptosis in human Philadelphia chromosome-positive lymphoblastic leukemia cell lines by treatment with the dual PPARalpha/gamma ligand TZD18. Blood 107: 3683-3692.

27. Laemmli UK (1970) Cleavage of structural proteins during the assembly of the head of bacteriophage T4. Nature 227: 680-685.

28. Towbin H, Staehelin T, Gordon J (1979) Electrophoretic transfer of proteins from polyacrylamide gels to nitrocellulose sheets: procedure and some applications. Proc Natl Acad Sci USA 76: 4350-4354.

29. Jiang WG, Sampson J, Martin TA, Lee-Jones L, Watkins G, et al. (2005) Tuberin and hamartin are aberrantly expressed and linked to clinical outcome in human breast cancer: The role of promoter methylation of TSC genes. Eur J Cancer 41: 1628-1636.

30. Goyal A, Martin TA, Mansel RE, Jiang WG $(2008)$ Real time PCR analyses of expression of E-cadherin, alpha-, beta and gammacatenin in human breast cancer for predicting clinical outcome. World J Surgical Oncol 6: 50-56

31. Wei Y, Yuan FJ, Zhou WB, Wu L, Chen L, et al. (2016) Boraxinduced apoptosis in HepG2 cells involves p53, BCl-2, and Bax. Genet Mol Res 15: 1-10.

32. Stahl S, Ittrich C, Marx-Stoelting P, Kohle C, Altug-Teber, et al. (2005) Hepatology 42: 353-361.

33. Li X, Yang G, Li X, Zhang Y, Yang J, et al. (2013) Traditional Chinese medicine in cancer care: A review of controlled clinical studies published in Chinese. PLoS One 8: e60338.

34. Edris AE (2009) Anti-cancer properties of Nigella spp. essential oils and their major constituents, thymoquinone and betaelemene. Curr Clin Pharmacol 4: 43-46.

35. Salim LZ, Mohan S, Othman R, Abdelwahab SI, Kamalidehghan B, et al. (2013) Thymoquinone induces mitochondria-mediated apoptosis in acute lymphoblastic leukaemia in vitro. Molecules 18: $11219-11240$.

36. Hong M, Yin HD, Chen SW, Wang DQ (2010) Synthesis and structural characterization of organotin (IV) compounds derived from the self-assembly of hydrazone Schiff base series and various alkyltin salts. J Organomet Chem 695: 653-662.

37. Rehman W, Badshah A, Khan S, Tuyet le TA (2009) Synthesis, characterization, antimicrobial and antitumor screening of some diorganotin (IV) complexes of 2-[(9H-Purin-6-ylimino)]-phenol. Eur J Med Chem 44: 3981-3985.

38. Basu Baul TS, Mizar A, Song X (2006) Dibenzyltin(IV) complexes of the 5-[(E)-2-(aryl)-1-diazenyl]quinolin-8-olates: Synthesis and an investigation of structures by X-ray diffraction, solution and 
solid-state tin NMR, 119 Sn Mössbauer and electrospray ionization MS. J Organomet Chem 691: 2605-2613.

39. Chen YC, Shen SC, Lee WR (2002) Emodin induces apoptosis in human promyeloleukemic $\mathrm{HL}-60$ cells accompanied by activation of caspase 3 cascade but independent of reactive oxygen species production. Biochem Pharmacol 64: 1713-1724.

40. Bhat FA, Sharmila G, Balakrishnan S, Arunkumar R, Elumalai P, et al. (2014) OSCP reverses EGF-induced epithelial to mesenchymal transition and invasiveness in prostate cancer (PC-3) cell line via EGFR/PI3K/Akt pathway. J Nutr Biochem 25: 1132-1139.

41. Fani S, Kamalidehghan B, Mun Lo K, Hashim NM, Chow KM, et al. (2015) Synthesis, structural characterization, and anticancer activity of a monobenzyltin compound against MCF-7 breast cancer cells. Drug Des Devel Ther 9: 6191-6201.

42. Hong $M$, Geng $H$, Niu M, Wang F, Li D, et al. (2014) Organotin (IV) complexes derived from Schiff base $\mathrm{N}^{\prime}-[(1 \mathrm{E})$-(2-hydroxy-3methoxyphenyl)methylidene]pyridine-4-carbohydrazone: synthesis, in vitro cytotoxicities and DNA/BSA interaction. Eur J Med Chem 86: 550-61

43. Esmaeili MA, Farimani MM, Kiaei M (2014) Anticancer effect of calycopterin via PI3K/Akt and MAPK signaling pathways, ROSmediated pathway and mitochondrial dysfunction in hepatoblastoma cancer (HepG2) cells. Mol Cell Biochem 397: 17-31.

44. Garufi A, Ubertini V, Mancini F, D'Orazi V, Baldari S, et al. (2015). The beneficial effect of Zinc (II) on low-dose chemotherapeutic sensitivity involves p53 activation in wild-type p53-carrying colorectal cancer cells. JECCR 34:87-95.

45. Ding HD, Zhang $X H, X u$ SC, Sun LL, Jiang MY, et al. (2009) Induction of protection against paraOSCPat-induced oxidative damage by abscisic acid in maize leaves is mediated through mitogen-activated protein kinase. J Integr Plant Biol 51: 961-972.

46. Schaller MD (2001) Biochemical signals and biological responses elicited by the focal adhesion kinase. Biochim Biophys Acta 1540:1-21.
47. Martins M, Baptista PV, Mendo AS, Correia C, Videira P, et al. In vitro and in vivo biological characterization of the antiproliferative potential of a cyclic trinuclear organotin (IV) complex. Molecular BioSystems 12: 1015-1023.

48. Fan L, Wang H, Xia X, Rao Y, Ma X, et al. (2012) Loss of Ecadherin promotes prostate cancer metastasis via upregulation of metastasis-associated gene 1 expression Oncol Lett 4: 1225-1233.

49. Li G, Li K, Satayamoorthy M, Herlyn S (2002) Dynamics of cell interactions during melanoma development. Crit Rev Oral Biol Med 13: 62-70.

50. Wetering M, Barker N, Harkes IC, Heyden M, Dijk NJ (2001) Mutant E-cadherin breast cancer cells do not display constitutive Wnt signaling. Cancer Res 61: 278-284.

51. Schackmann RC, Amersfoort M, Haarhuis JH, Vlug EJ, Halim VA (2011) Cytosolic p120-catenin regulates growth of metastatic lobular carcinoma through Rock1-mediated anoikis resistance. J Clin Invest 212: 3176-88.

52. Ferreira AC, Suriano G, Mendes N, Gomes B, Wen X (2012) Ecadherin impairment increases cell survival through Notchdependent upregulation of Bcl-2. Hum Mol Genet 21: 334-343.

53. Bryant DM, Stow JL (2004) The ins and outs of E-cadherin trafficking. Trends Cell Biol 14: 427-434.

54. Chen YT, Stewart DB, Nelson WJ (1999) Coupling assembly of the E-cadherin/beta-catenin complex to efficient endoplasmic reticulum exit and basal-lateral membrane targeting of $\mathrm{E}-$ cadherin in polarized MDCK cells. J Cell Biol 144: 687-699.

55. Miranda KC, Khromykh T, Christy P, Le TL, Gottardi CJ, et al. (2001) A dileucine motif targets E-cadherin to the basolateral cell surface in Madin-Darby canine kidney and LLC-PK1 epithelial cells. J Biol Chem 276: 22565-22572. 